Robert Dale. (C) 2010 Journal of Contemporary History This is a post print version of article published in the Journal of Contemporary in January 2010. This is the author's version of the work. It is posted here by permission of the copyright holder for personal use, not for redistribution. The definitive version was published in The Journal of Contemporary History, 45:1, doi:10.1177/0022009409348964

This article was awarded the 2010 George L. Mosse Prize.

\title{
Rats and Resentment: The Demobilization of the Red Army in Postwar Leningrad, 1945-50*
}

\begin{abstract}
This article reassesses the myth of the heroic homecoming and successful reintegration of Red Army veterans returning to Leningrad after 1945. Soviet propaganda created an official version of demobilization, which presented veterans as exemplary citizens who returned to civilian life with relative ease. This myth created the impression that ordinary Leningraders welcomed home returning veterans as heroes. Throughout the twentieth century the demobilization of mass conscript armies generated tensions and difficulties. Across Europe the experience of demobilization in the wake of industrialized warfare created resentment, disaffection and anger. In contrast to official myths, Leningrad's veterans were little different from their counterparts elsewhere. Reports based on veterans' letters intercepted by the military censor reveal that many ex-servicemen were deeply resentful of the reception they received in postwar Leningrad. The frustrations of demobilization were blamed on 'rear-line rats', a term of derision for officials believed to have shirked front-line service in favour of safer administrative jobs. These problems were not imagined by disaffected veterans. Other documents confirm that corruption and bureaucracy were widespread problems. Despite these simmering resentments, the myth of a successful demobilization has remained remarkably durable and continues to be accepted by historians and the general population.
\end{abstract}

Keywords:

demobilization, Leningrad, myth, Soviet Union, veterans

\footnotetext{
* This article is derived from a larger PhD project generously funded by the Arts and Humanities Research Council of the United Kingdom (AHRC). I am particularly grateful to the AHRC for supporting an extended period of archival research in St Petersburg and Moscow. I would also like to thank members of the 'History Lab' seminar at the Institute of Historical, University of London for an opportunity to present and discuss an earlier version of this article. I am also indebted to the advice and criticism of Catherine Merridale and Richard Bessel; naturally they bear no responsibility for the ideas contained within this article.
} 
On Sunday 8 July 1945 a military parade through the streets of Leningrad was organized to honour the city's heroic wartime defenders. Tens of thousands of Leningraders thronged the streets, expecting to receive the specially chosen guards' regiments in a manner befitting heroes. The spectacle of thousands of pristine-looking soldiers marching past in disciplined lines thrilled the jubilant crowds. Even the heavy police presence failed to dampen the crowd's spirits. The parade received extensive local and national press coverage. Articles and photographs recorded women and children showering the troops with bouquets of flowers and reported poignant cases of soldiers reunited with families after years of separation. ${ }^{1}$ The same pomp and circumstance characterized the welcoming ceremonies for demobilized soldiers, who from mid-July 1945 began arriving in their thousands. In the early days of mass demobilization, cheering women and children crowded the platforms of railway stations, anxious to be reunited with their loved ones. ${ }^{2}$ Similar ceremonies were organized in cities, towns and villages across the Soviet Union.

Officially, returning soldiers were welcomed home as heroes, were given extensive state assistance and quickly readapted to normal civilian life. In reality, few veterans received the heroes' welcome described in the press. Many were disappointed by the reception they received. This article seeks to challenge the official myths surrounding demobilization in Leningrad. First, it sketches the contours of these myths and contrasts them with the experience of other demobilizing armies and societies. It then documents the resentment provoked by the difficulties of demobilization, a problem largely obscured by Soviet propaganda. The article focuses upon the resentments created by veterans' interaction with the state apparatus responsible for easing their reintegration. Popular opinion sources,

\footnotetext{
${ }^{1}$ On 10 July 1945 Leningradskaya pravda devoted three of its four pages to coverage of the parade. 'Leningrad vstrechaet geroev-gvardeitsev', Krasnaya zvezda, 10 July 1945, 2; 'Leningrad vstrechaet geroicheskikh voinov', Trud', 10 July 1945, 2; 'Nezabyvaemyi den', Leningradskii universitet, 13 July 1945, 2. Many thanks to the Museum of the History of Saint Petersburg State University for sharing a newly acquired diary containing the reactions of a student to the parade and its policing.

2 Eshelon prishel iz Berlina... Leningradtsy vstrechaiut voinov pobeditelei’, Smena, 1 August 1945, 1;

'Vstrecha pobeditelei', Smena, 2 August 1945, 1.
} 
corroborated by official documents, reveal that the transition to normal civilian life was far from simple. Angered and frustrated by the reality of demobilization, Leningrad's veterans blamed corrupt bureaucrats for their woes. In making these arguments and uncovering these largely forgotten resentments, the article draws on a wealth of archival materials and neglected published sources, many never previously examined.

In the first weeks of demobilization Leningrad's returning veterans were greeted with fanfares, bunting and celebrations. This jubilation was not entirely spontaneous, but rather the product of an orchestrated propaganda campaign. In response to national directives, the Leningrad party's propaganda organs mobilized their resources to create the impression that demobilized soldiers returned to a heroes' welcome. ${ }^{3}$ Propaganda aimed to persuade Leningraders of the need to treat veterans with respect and surround them with care and attention. Leningrad's Komsomol cells made frantic preparations to ensure that the city’s railway platforms were bedecked with banners, flowers, posters and portraits of Stalin. ${ }^{4}$ The propaganda apparatus encouraged local and regional newspapers to report upon these celebrations, the enthusiastic reintegration of veterans into the workplace and their contribution to the nation's social and political life. Posters and a new genre of article celebrated the exemplary discipline and productivity of former soldiers. ${ }^{5}$ The state went to considerable lengths to ensure that veterans were aware of the benefits available to them, even if they did not always understand the finer detail. Demobilization legislation and details of benefits were published widely in the press and reproduced in convenient pocket-books.

\footnotetext{
${ }^{3}$ For a more detailed examination of this process, see Mark Edele, Soviet Veterans of the Second World War: A Popular Movement in an Authoritarian Society, 1941-1991 (Oxford 2008), 7-8, 22-38; and Catherine Merridale, Ivan's War: The Red Army 1939-1945 (London 2005), 310-12.

${ }^{4}$ Central State Archive of Historical-Political Documentation of Saint Petersburg [hereafter 'TsGAIPD SPb'] K-598/5/232/16-17, 24/2v/7023/75, 88; 'Vstrechaem dorogykh voinov’, Smena, 16 July 1945, 2; Merridale, Ivan's War, op. cit., 309-11.

${ }^{5}$ Russian State Archive of Social and Political History [hereafter 'RGASPI'] 17/122/147/181-2. For typical examples of the articles stressing the exemplary qualities of veterans, see 'Trudovoi vklad', Vechernyi Leningrad, 20 February 1946, 1; and 'Zolotoi fond zavodi', Vechernyi Leningrad, 4 March 1946, 1. For examples of propaganda posters, see N.N. Glushko, Velikaya pobeda i vozrozhdenie Moskvy (Moscow 2005), 44, 51, 62, 79.
} 
Before soldiers were demobilized, officers and party agitators explained entitlements in speeches, lectures and individual consultations. ${ }^{6}$ Soviet propaganda asserted that veterans enjoyed a special status unimaginable in the capitalist West. The national satirical journal Krokodil' published a series of cartoons depicting the plight of unemployed American veterans, which contrasted sharply with the cheerful depiction of Soviet veterans. ${ }^{7}$ A statesponsored publishing house even published a short pamphlet for British readers which demonstrated the care and support lavished on Soviet war invalids. ${ }^{8}$ Propaganda presented demobilization as a smooth process through which veterans were reintegrated into the labour force, and which demonstrated their value as exemplary citizens.

The propaganda image of the heroic welcome and successful reintegration of Soviet veterans has proved remarkably durable. For a country reeling from the material and social costs of war, the rapid demobilization of eight and a half million soldiers by the end of 1948 was a remarkable achievement. This success has largely obscured the difficulties and hardships of demobilization. Few Russians can now remember a time when veterans of the Great Patriotic War were not a privileged stratum of society. Over time a patriotic cult of war developed, which enshrined the Great Patriotic War as a foundational moment for Soviet culture. Under Brezhnev war veterans became valued and prominent members of society, rewarded with enhanced pensions and supplementary benefits. ${ }^{9}$ Each and every May, when Russians celebrate their victory, the photographs and newsreels of victory parades, homecoming troops and joyous family reunions taken in the summer of 1945 reappear in newspapers, on posters and in television broadcasts. Veterans remain at the centre of the ritualized celebration of Victory Day (Den Pobedy) on 9 May; a day on which they receive

\footnotetext{
6 'Politicheskaya rabota s demobilizyemymi', Krasnaya zvezda, 13 July 1945, 1.

7 Krokodil', 34 (30 October 1945), 12; 30-31 (October-November 1946), 16; 12 (30 April 1947), 8.

${ }^{8}$ P.P. Verzhibilovsky, The Care of War Pensioners in Russia (London 1945).

${ }^{9}$ On the cult of the Great Patriotic War and the status of veterans, see Nina Tumarkin, The Living and the Dead: The Rise and Fall of the Cult of World War II in Russia (New York 1994); Amir Weiner, Making Sense of War: The Second World War and the Fate of the Bolshevik Revolution (Princeton, NJ, and Oxford 2001); and Michael Ignatieff, 'Soviet War Memorials', History Workshop 17 (Spring 1984), 157-63.
} 
the thanks of local and national politicians, gifts from former employers and the adulation of friends and relatives. Veterans were not always so fortunate, but this cultural context makes discussing \&ndash; especially with a foreigner \&ndash; the hardships of late Stalinism, the lack of support after demobilization and the unwelcoming attitude of Leningraders extremely difficult. Official myths and their modern reincarnations have served many veterans well, helping them forget the darker memories of war and the perceived insults of demobilization. ${ }^{10}$

Soviet, Russian and western historians have found the official narrative of demobilization beguiling and have failed to systematically undermine patriotic myths. The few Soviet scholars to examine demobilization in any depth concentrated upon the ways in which returning soldiers swelled the ranks of the industrial and agricultural workforces and local party organizations. ${ }^{11}$ In continuing to portray veterans as highly skilled and motivated exemplary citizens, in terms which differed little from the propaganda of the first few postwar years, Soviet historians helped reinforce official myths. This interpretation still influences the perception of Great Patriotic War veterans today. Prior to the 'archival revolution', Western historians, although acknowledging difficulties, broadly accepted that veterans were rapidly and successfully reintegrated into the workforce and that they enjoyed a privileged position in postwar society. Veterans, it was argued, were an upwardly mobile group promoted to administrative and managerial positions in factories, offices and collective farms. Many enjoyed relative freedom of movement, privileged access to education and greater opportunity to join the party. ${ }^{12}$ Of course, much of this was true and has been confirmed by the opening of the archives. The archival record is dominated by reports

${ }^{10}$ Catherine Merridale, 'Culture, Ideology and Combat in the Red Army', Journal of Contemporary History 41(2) (April 2006), 305-24, at 307-9.

11 V.N. Donchenko, 'Demobilizatsiya Sovetskoi Armii i reshenie problemy kadrov v pervye poslevoennye gody’, Istoriya SSSR 3 (1970), 96-102; V.A. Ezhov, 'Izmeneniya v chislennosti i sostave rabochikh Leningrada v poslevoennyi period (1945-1950gg.)’, Vestnik Leningradskogo Universiteta, Seriya istorii, yazyka i literatury 2 (1966), 15-21.

12 Sheila Fitzpatrick, 'Postwar Soviet Society: The “Return to Normalcy” 1945-1953', in Susan J. Linz (ed.), The Impact of World War II on the Soviet Union (Totowa, NJ, 1985), 129-156, at 136-7; Sheila Fitzpatrick, 'War and Society in Soviet Context: Soviet Labour before, during and after World War II', International Labour and Working Class History 35 (Spring 1989), 37-52. 
addressing the official priorities of demobilization, re-employment and reintegration in party structures. Unsurprisingly, archival studies continue to argue that veterans were beneficiaries of the postwar reordering of Soviet society. ${ }^{13}$ In Amir Weiner's study of postwar Vinnitsa, veterans emerge as a powerful and assertive group who dominated the local party. ${ }^{14}$ Mark Edele's recent research has provided the most detailed and rounded portrayal of Soviet veterans to date. ${ }^{15}$ Although Edele examines the difficulties faced by returning veterans in detail, he continues to suggest that some groups of veterans improved their social position after demobilization. ${ }^{16}$ The impression of demobilization derived from central archives and official reports, however, tells only part of the story. There are other ways of looking at Soviet veterans' experience of demobilization. While some veterans enjoyed improved social mobility in the medium to long term, in the shorter term the experience of homecoming rarely felt like a step up the social ladder.

The official myth of the Red Army's successful demobilization sits uncomfortably alongside the experience of other demobilizing armies and societies. Reintegrating war veterans creates difficulties for any society, but throughout the twentieth century the process of demobilizing mass conscript armies after the violence of modern industrialized warfare proved exceptionally difficult. Compared with the heroic images dominant in Soviet and modern Russia, in the West disgruntled and disenchanted veterans struggling to readjust to civilian life are more common. Damaged veterans are just as familiar from the histories of war and demobilization as they are from literary accounts of the First World War or filmic portrayals

\footnotetext{
13 See, for example, Kees Boterbloem, Life and Death under Stalin: Kalinin Province, 1945-1953 (Montreal and London 1999), 60-3; and Eric J. Duskin, Stalinist Reconstruction and the Confirmation of a New Elite, 1945-1953 (Basingstoke 2001), 17-21.

14 Weiner, Making Sense, op. cit.

15 Edele, Soviet Veterans, op. cit.; and Mark Edele, ‘A “Generation of Victors?” Soviet Second World War Veterans from Demobilization to Organization, 1941-1956’, PhD dissertation, University of Chicago, 2004; Mark Edele, 'Soviet Veterans as an Entitlement Group, 1945-1955', Slavic Review 65(1) (Spring 2006), 111-37; Mark Edele, 'More than Just Stalinists: The Political Sentiments of Victors 1945-1953', in Juliane Fürst (ed.), Late Stalinist Russia: Society Between Reconstruction and Reinvention (London 2006), 167-91.

16 See in particular Edele, Soviet Veterans, op. cit., 129-49.
} 
of Vietnam veterans. ${ }^{17}$ It is hard to imagine how the history of the impact of war could be written in the West without reference to mental and physical traumas or the failure of some veterans to readjust.

The difficulties experienced by veterans of the Great War have attracted the most detailed and rigorous historical examination. Finding work, somewhere to live and readjusting created difficulties in all combatant nations. Many came to resent a perceived lack of support, recognition and understanding from wider society. French veterans, according to Antoine Prost, often returned to civilian life irritated by the 'petty meanness' of officials. A ‘semi-revolutionary anger’ was directed at the civilians, shirkers and new rich whom returning veterans blamed for the frustrations and disappointments of peacetime. ${ }^{18}$ Many British veterans were destabilized by the 'dissonance between real and imagined civilian life', which led to feelings of frustration, anger, resentment and confusion. ${ }^{19}$ Although the image of demobilized German veterans returning to the scorn of civil society is largely false, many veterans believed the myth that ungrateful civilians failed to welcome them home. ${ }^{20}$ The difficulties of demobilization stretched beyond Europe. American, Canadian, Australian and New Zealand veterans of the First World War encountered similar frustrations and expressed disappointment, anger and resentment. ${ }^{21}$ Irrespective of nationality, the problems

\footnotetext{
17 Here I am thinking of popular novels, such as Pat Barker's Regeneration Trilogy: Regeneration (London 1990), The Eye in The Door (London 1993) and The Ghost Road (London 1995); and Sebastian Faulks, Birdsong (London 1994). On Vietnam veterans in film, see Martin D. Norden, 'Bitterness, Rage and Redemption: Hollywood Constructs the Disabled Vietnam Veteran’, in David A. Gerber (ed.), Disabled Veterans in History (Ann Arbor, MI, 2000), 96-114.

18 Antoine Prost, trans. Helen McPhail, In the Wake of War: Les Anciens Combattants and French Society (New York 1992), 32-3.

19 Dan Todman, The Great War: Myth and Memory (London and New York 2005), 11; Denis Winter, Death's Men: Soldiers of the Great War (Harmondsworth 1979), 236-51.

20 Richard Bessel, 'The Great War in German Memory: The Soldiers of the First World War, Demobilisation and Weimar Political Culture', German History 6(1) (January 1988), 20-34; Richard Bessel, Germany after the First World War (Oxford 1993).

21 Alistair Thompson, Anzac Memories: Living With the Legend (Oxford 1994); Desmond Morton and Glenn Wright, Winning the Second Battle: Canadian Veterans and the Return to Civilian Life, 1915-1930 (Toronto 1990).
} 
of readjustment were magnified for the war disabled, who had to face the added frustration of obtaining pensions and the greater potential for administrative injustices. ${ }^{22}$

The failures to reintegrate veterans after 1918 loomed large over planning for mass demobilization during the Second World War. Although the second world war continues to evoke pride and be presented as the 'good war', in both Britain and America there was genuine concern that damaged and disaffected veterans would create widespread social problems. ${ }^{23}$ In 1944 the team of sociologists working for the US Army research branch predicted

an increase in expressions of the feeling that civilians made no real sacrifices and that they had no real appreciation of / what the soldier went through and would forget him now the danger was past. ${ }^{24}$

In March 1944, in a paper intended for broadcasters transmitting to British forces, Lieutenant T.F. Main anticipated that demobilization would be characterized by grumbling about unfairness, impatience, indiscipline, depression and 'epidemics of jealousy and resentment' directed against civilians. ${ }^{25}$

Making comparisons with the Decembrist Uprising of 1825, conducted by disaffected officers of the Napoleonic Wars, several historians have suggested veterans of the Great Patriotic War were feared as potential 'neo-Decembrists'.${ }^{26}$ Although the ubiquitous

\footnotetext{
${ }^{22}$ Prost, In the Wake of War, op. cit, 28-9; Deborah Cohen, The War Come Home: Disabled Veterans in Britain and Germany, 1914-1939 (Berkeley, CA, 2001).

${ }^{23}$ Joanna Bourke, “'Going Home”: The Personal Adjustment of British and American Servicemen after the War', in Richard Bessel and Dirk Schumann (eds), Life after Death: Approaches to the Social History of Europe During the 1940s and 1950s (Cambridge 2003), 149-60; Joanna Bourke, An Intimate History of Killing: Face to Face Killing in the Twentieth Century (London 2000), 345-68; David A. Gerber, 'Heroes and Misfits: The Troubled Social Reintegration of Disabled Veterans in the Best Years of Our Lives', in Gerber (ed.), Disabled Veterans in History (Ann Arbor, MI, 2000), 70-95, at 70-2.

${ }^{24}$ S.A. Stouffer (ed.), The American Soldier, vol. 2 (Princeton, NJ, 1949), 582-3.

25 Quoted in Barry Turner and Tony Rennell, When Daddy Came Home: How Family Life Changed Forever in 1945 (London 1995), 42-3; and Julie Summers, Stranger in the House: Women's Stories of Men Returning from the Second World War (London 2008), 10.

${ }^{26}$ Elena Zubkova, trans. Hugh Ragsdale, Russia After the War: Hopes, Illusions and Disappointments, 19451957 (Armonk, NY, and London 1998), 25; Elena Zubkova, Poslevoennoe sovetskoe obshshestvo: Politika i povsednevnost' 1945-1953 (Moscow 2000), 32; E.S. Senyavskaya, 'Dukhovnyi oblik frontovogo pokoleniya: istoriko-psikhologicheskii ocherk’, Vestnik Moskovskogo Universiteta, Seriya 8 Istoriya 2 (July-August 1992),
} 
propaganda campaign was designed to forestall resentment, concerns about the potential for opposition amongst veterans were confined to Stalin, his ruling circle and the security services. At a lower level there seems to have been no public and little private discussion of the potential difficulties posed by disaffected Red Army veterans comparable with discussions in the West. Given the historical precedents available to local administrators, planners and party leaders, it is surprising that the resentments demobilization created were neither predicted nor discussed in detail. The Russian Empire encountered difficulty reintegrating veterans and their families from the eighteenth century, if not earlier. ${ }^{27}$ Contemporaries might have drawn direct comparisons with events within living memory. The revolutions of 1905 and 1917 and the Kronstadt uprising of 1921, key moments in the Bolshevik consciousness, surely demonstrated the risks. The chaotic demobilization of veterans of the first world war and Russian Civil War created real social problems and frustrations and resulted in the militarization of wider Soviet society. ${ }^{28}$ It is hard to believe that Leningrad's leaders, representative of a party state forged in the crucible of war, governing a city at the very centre of the Bolshevik revolution, were entirely ignorant of the threats posed by discontented soldiers. Contrary to patriotic myths, in official Soviet propaganda Red Army veterans were not immune from the disappointments and frustrations so frequently experienced by ex-servicemen throughout the twentieth century.

The experiences of veterans returning to, or arriving in, Leningrad and its environs represented an extreme example of difficulties faced by Soviet veterans of the Great Patriotic War, but also European veterans of twentieth-century total warfare. Four long years of brutal 39-51, at 50-1; E.S. Senyavskaya, Frontovoe pokolenie: Istoriko-psikhologicheskie issledovanie, 1941-1945 (Moscow 1995), 91.

27 Elise Kimerling Wirtschafter, 'Social Misfits: Veterans and Soldiers' Families in Servile Russia', The Journal of Military History 59(2) (April 1995), 215-35, at 228.

28 Allan K. Wildman, The End of the Russian Imperial Army, vol. 1, The Old Army and the Soldiers' Revolt (March-April 1917) (Princeton, NJ, 1980), and vol. 2, The Road to Soviet Power and Peace (Princeton, NJ, 1987); Mark von Hagen, Soldiers in the Proletarian Dictatorship: The Red Army and the Soviet Socialist State, 1917-1930 (Ithaca, NY, and London 1990), 127-58; Sheila Fitzpatrick, 'The Legacy of the Civil War', in Diane P. Koenker et al. (eds), Party, State, and Society in the Russian Civil War: Explorations in Social History (Bloomington, IN, 1989), 385-98. 
warfare brought profound disruption for cities across the Soviet Union. Many cities suffered enormous losses to their pre-war housing stocks. Between 1941 and 1945 Smolensk lost approximately 88 per cent of its housing, Voronezh 83 per cent and Rostov-on-Don 75 per cent. ${ }^{29}$ In Novgorod before the war there were 2346 residential buildings; by February 1944 only 15 were habitable. ${ }^{30}$ Demobilized soldiers returning to Stalingrad would have found a city reduced to rubble, their families living in basements or dugouts. ${ }^{31}$ Veterans everywhere experienced considerable difficulty in readjusting to civilian life. Although Leningrad's urban infrastructure suffered less damage than many places, the Soviet Union's second city was amongst the worst affected of major Soviet cities. While Kiev, for example, suffered greater destruction, it had to assimilate considerably fewer demobilized veterans. By January 1947 a total of 44,571 veterans had been demobilized in Kiev, compared with 211,199 in Leningrad. ${ }^{32}$ In addition to the greater pressure of numbers, the city's unique experience of war and blockade combined to make the difficulties of demobilization in postwar Leningrad particularly acute. Veterans across the Soviet Union noticed the disparity between the reality of civilian and official propaganda, but these differences were particularly apparent in Leningrad.

Demobilization in Leningrad was anything but a return to normality. ${ }^{33}$ Veterans could not even rely upon returning to their pre-war homes and families, let alone their jobs. A total of 3174 buildings with living-space of 3.3 million square metres had been destroyed. Approximately 9000 buildings were dismantled for firewood. A further 2.2 million square

\footnotetext{
29 Mark B. Smith, 'Rubble to Communism: The Urban Housing Programme in the Soviet Union, 1944-1964', PhD dissertation, School of Slavonic and East European Studies, University College, London, 2007, 48; Jeffrey W. Jones, 'People Without A Definite Occupation: The Illegal Economy and "Speculators" in Rostov-on-theDon, 1943-48’, in Donald J. Raleigh (ed.), Provincial Landscapes: Local Dimensions of Soviet Power, 19171953 (Pittsburgh, PA, 2001), 236-54.

30 RGASPI/88/313/126.

31 John Steinbeck, A Russian Journal (London 1949), 120.

32 Edele, 'A “Generation of Victors?”', Appendix 7, op. cit., 585-6.

33 On normality after the war, see Fitzpatrick, 'Postwar Soviet Society’, op. cit., 129.
} 
metres, spread across 7143 buildings, were so severely damaged as to be uninhabitable. ${ }^{34}$ Between 500,000 and 1 million Leningraders were made homeless by wartime destruction. ${ }^{35}$ Outside the city, the countryside resembled a war zone. Vast swathes of the Leningrad region were laid waste. An estimated 81,843 residential buildings were destroyed, leaving many rural districts unrecognizable. The rural towns of Mga, Kolpino and Tosno stood in ruins, losing respectively 97.5, 85 and 70 per cent of their housing. In the Tosnenskii district alone, 169 villages and 12,811 homes were destroyed..$^{36}$ Despite extensive efforts to rebuild housing, many veterans returned to find their homes destroyed or occupied by others. Reconstruction would take many years.

Leningrad, the crucible of revolution and bastion of the working class, was a shadow of its former self. There were visibly fewer people. In 1945 Leningrad's population was approximately a third of its pre-war level. Over 700,000 residents starved or froze to death during the blockade, and around 1.3 million Leningraders were evacuated. Many never returned. ${ }^{37}$ Outside the city, the population of the Leningrad region was reduced from 1,506,400 in January 1941 to 414,900 in October $1944 .{ }^{38}$ Nothing was quite the same in this ruined and depopulated landscape. Not only did it look different, but it was home to different people, who behaved in different ways. The arrival of hundreds of thousands of rural migrants helped repopulate the city. Native Leningraders often blamed these newcomers, who allegedly exhibited lower 'cultural' levels, for declining postwar standards in manners,

\footnotetext{
${ }^{34}$ V.I. Piliavskii, ‘Arkhitektura i stroitel'stvo', in Ocherki istorii Leningrad, vol. 6 (Leningrad 1970), 207-30, at 207; A.Z. Vakser, Leningrad Poslevoennyi 1945-1982 gody (St Petersburg 2005), 71.

${ }^{35}$ Vakser, Leningrad, op. cit., 71, 76; and 'Vo slavy rodnogo Goroda', Leningradskaya pravda, 7 November 1947, 3.

${ }^{36}$ RGASPI/17/88/313/26-7. 'O stroitel’stve zhilykh domov kolkhoznikov proizvodstvennykh postroek kolkhozov kul'turno-bytovykh zdanii v raionakh Leningradskoi oblasti, podverdavshikhsya ot nemetskoi okkupatsii', Reshenie deviatoi sessii Leningradskogo oblastnogo soveta deputatov trudyashchikhsya ot 9-10 avgusta 1945 goda (Leningrad 1945), 3-12, at 3; Propaganda i agitatsiya 16 (August 1945), 20-8; 'Novoe Kolpino - Vorozhdenie goroda’, Vechernyi Leningrad, 16 February 1946, 2.

37 Vakser, Leningrad, op. cit., 10; Elizabeth White, 'After the War was Over: The Civilian Return to Leningrad', Europe-Asia Studies 59(7) (November 2007), 1145-61, at 1145-7.

38 A.R. Dzeniskevich (ed.), Iz raionov oblasti soobshchaiut...: Svobodnye ot okkupatsii raiony Leningradskoi oblasti v gody Velikoi Otechestvennoi voiny: 1941-1945. Sbornik dokumentov (St Petersburg 2007), 510-11.
} 
hygiene and labour discipline. ${ }^{39}$ However, Leningraders themselves were transformed by the traumatic experience of war; former peasants were a convenient scapegoat for deeper changes in postwar society. The horrors of mass death and starvation hardened blockade survivors. The unique circumstances of the blockade created new local practices, modes of association and networks. Speculation in foodstuffs and basic goods became widespread. Corruption crept into local administration at almost every level. Demobilized soldiers found postwar Leningrad an alien environment.

The death and destruction wrought upon Leningrad and its people and the impact of wartime violence upon combatants made it difficult to sustain the myth that returning troops came home to popular acclaim. Postwar Leningrad was a colder, harder and harsher place than veterans remembered. Few Leningraders afforded returning former soldiers any form of special treatment. Most people were preoccupied with resolving their own problems rather than welcoming home ex-servicemen. Blockade survivors, returning evacuees, migrants and demobilized veterans were in competition for jobs, housing and the state's meagre resources. For the vast majority of veterans the public discourse of a city welcoming home its proud defenders grated with the reality of demobilization. The state encouraged veterans to forget about the horrors of war and the injustices of demobilization and get on with their lives. Kirschenbaum even argues that the state’s ‘amnesiac agenda’ extended as far as reconstructing the city in a way which obliterated physical reminders of the war. ${ }^{40}$ For individuals, forgetting was preferable to endlessly reliving painful memories. ${ }^{41}$ The myth that veterans were reintegrated with little difficulty, like the construction of a heroic myth of the blockade and the designation of Leningrad as a 'Hero City', was part of a wider attempt to

39 Blair A. Ruble, 'The Leningrad Affair and the Provincialization of Leningrad', Russian Review 42(3) (July 1983), 301-20, at 304-8; and White, 'After the War was Over’, op. cit., 1158.

40 Lisa A. Kirschenbaum, The Legacy of the Siege of Leningrad, 1941-1945: Myth, Memories and Monuments (Cambridge 2006), 116-7.

${ }^{41}$ Catherine Merridale, 'Death and Memory in Modern Russia', History Workshop Journal 42 (Autumn 1996), 1-18, at 12; Catherine Merridale, Night of Stone: Death and Memory in Twentieth-Century Russia (London 2000), 251. 
create a usable narrative of the wartime past. ${ }^{42}$ In the immediate aftermath of war, however, many veterans were unable to forget. Contrary to the propaganda image of ex-servicemen as exemplary citizens, Leningrad's veterans were deeply resentful of their treatment during and after demobilization.

The frustrations inherent in demobilization began while many soldiers were still in uniform. Many soldiers would have to wait months, if not years, before they finally returned home. Rather than the points-based systems favoured by the British and Americans, the Red Army was demobilized by age group. The demobilization law passed on 23 June 1945 applied to the 13 oldest age groups (men born between 1893 and 1905). ${ }^{43}$ Relatively few soldiers of this age group remained in armed service. Yuri Popov recalled the day when the law was announced to the massed ranks of his regiment. The soldiers to whom the law applied were ordered to take a pace forward; there were only four. ${ }^{44}$ On 25 September 1945 demobilization was extended to the next ten birth cohorts and soldiers who had completed higher, technical or agricultural education, former teachers and lecturers, students, people who had sustained three or more wounds, soldiers with seven or more years' continuous service, and women. A further decree, passed on the 20 March 1946, the third wave of demobilization, applied to soldiers born between 1916 and 1921. The youngest age groups waited until the spring of 1948 before becoming eligible for release. ${ }^{45}$ By 1946 the bunting, thronged crowds and military orchestras had long since disappeared. The majority of

\footnotetext{
${ }^{42}$ Here I have in mind something similar to the creation of public memory in the Federal Republic of Germany, as described in Robert G. Moeller, War Stories: The Search for a Usable Past in the Federal Republic of Germany (Berkeley, CA, 2001).

43 'Zakon - O demobilizatsii starshikh vozrastov lichnogo sostava deitvuiushchei armii', Leningradskaya pravda, 24 June 1945, 1.

44 'Na voine spasal iumor', Argumenty i fakty - Peterburg 19 (2007), 4.

${ }^{45}$ O demobilizatsii vtoroi ocheredi lichnogo sostava Krasnoi Armii', Trud', 26 September 1945, 1; Edele, 'A

“Generation of Victors?”', op. cit., 62-8; Edele, Soviet Veterans, op. cit., 23.
} 
returning soldiers never experienced anything approaching the public acclaim of the summer of $1945 .^{46}$

Irrespective of the hardships in postwar Leningrad, soldiers longed to return home. ${ }^{47}$ Letters written to families and wives in the period of limbo prior to demobilization were characterized by an impatience to escape the clutches of the army and regain control of their own lives. Before this long-awaited moment arrived, a number of frustrations and humiliations had to be endured. Shortage of uniforms meant that many veterans returned in incomplete or tattered uniforms. In his memoirs, Evgenii Moniushko recalled that in the autumn of 1945 soldiers in his regiment were stripped of their uniforms and footwear in order to clothe those about to be demobilized. ${ }^{48}$ Reports written by Leningrad's military prosecutor reveal that throughout 1945 and 1946 privileged NKVD troops were often released without the payments, supplies or equipment they were promised by officers and agitators and to which they were entitled. ${ }^{49}$ Similar problems were reported across the Soviet Union. For proud soldiers, shortages of underwear and the confiscation of personal property were deeply humiliating. ${ }^{50}$

Repeated delays and disappointments made the waiting unbearable. One veteran demobilized at the end of March 1950, interviewed as part of my research, recalled a feeling of disbelief when he was finally released. Waiting at the platform for the train home, two of his comrades were hauled back, having been mistakenly considered for release; for the rest of the journey he expected something similar to happen to him. ${ }^{51}$ The journey home involved

\footnotetext{
46 Merridale, Ivan's War, op. cit., 312.

47 Boris Mikhailov, Na dne blokady i voiny (St Petersburg 2000), 436-42; Evgenii D. Moniushko, trans. Oleg Sheremet, ed. David M. Glantz, From Leningrad to Hungary: Notes of a Red Army Soldier, 1941-1946 (New York 2005), 220-1.

48 Moniushko, Leningrad to Hungary, op. cit., 220.

49 Central State Archive of Saint Petersburg [hereafter 'TsGA SPb’] 9260/1/27/122,137 and 9260/1/30/76-7.

50 State Archive of the Russian Federation [hereafter 'GARF'] R-8131/37/2266/61-9.

51 As part of my research, I conducted a number of oral history interviews with veterans, arranged through veterans' organizations, St Petersburg Memorial and a charitable foundation linked to the Elektrosila plant. Here, interview held 21 March 2008, Disc No. 10, author’s own collection.
} 
further delays and discomfort. Mismanagement and the dilapidated railway network led to long journeys in cramped freight wagons, which were often halted unexpectedly for a number of days. Many veterans eased the boredom with vodka or industrial spirit, which on occasion resulted in mass alcohol poisoning. Violent brawls and disturbances helped punctuate seemingly endless journeys. ${ }^{52}$ The reality of demobilization was a world away from the propaganda of homecoming heroes showered in glory and plaudits.

Having finally arrived in Leningrad, the frustrations of demobilization were far from over; in many ways they were about to begin. Soldiers, in the writer Konstantin Simonov’s classic phrase, 'imagined life after the war as a holiday that would begin when the last shot was fired.' Peacetime was imagined 'in rainbow colours', which were quickly revealed to be a fantasy. Perhaps former soldiers did not expect to return to a flourishing country, but they certainly hoped that life would improve. ${ }^{53}$ Hope quickly turned to disappointment, as the full extent of the dissonance between wartime dreams and harsh postwar realities became apparent. Veterans found the masses of red tape characterizing demobilization very frustrating. Obtaining work, housing, food, clothing, pensions and healthcare required seemingly endless form-filling and queuing. The blame for the epidemic of bureaucracy and corruption hindering demobilization was laid upon 'rear-line rats' (tylovye krysi), a term of derision for administrators accused of shirking military service in preference for safe jobs at the rear. These callous bureaucrats became one of the main targets for veterans' resentment.

Veterans' angry reactions to the 'rats' were recorded in reports written by Leningrad's military censor, part of the regional secret police administration, and preserved in the secret archive of the Leningrad Soviet. These reports, headed 'special communications'

\footnotetext{
52 RGASPI/17/121/427/123-5; Edele, Soviet Veterans, op. cit., 22-30; V.A. Kozlov, Massovye besporiadki v SSSR pri krushcheve i brezhneve (1953 - nachalo 1980kh) (Novosibirsk 1999), 60-1; A.V. Vinogradov and A.V. Pleizher (eds), Bitva za Leningrad v syd'bakh zhiteli goroda i oblasti (vospominananiya zashchitnikov i zhitelei blokadnogo goroda i okkypirovannykh territorii) (St Petersburg 2005), 267.

53 Zubkova, Russia after the War, op. cit., 34-5; Geoffrey Hosking, Rulers and Victims: The Russians in the Soviet Union (Cambridge, MA, and London 2006), 236; and Moniushko, Leningrad to Hungary, op. cit., 248.
} 
(spetssoobshchenie), were based on excerpts of intercepted private letters written by veterans to their friends and families. During the war and for some time afterwards, letters written by and addressed to soldiers were routinely opened and read by the military censor. Surprisingly, the military censor continued to monitor ex-servicemen's correspondence. Many of these spetssoobshchenie contain detailed evidence of veterans' animosity towards the 'rear-line rats’. Outraged letters complaining of corruption and bureaucracy reveal widespread resentment towards administrators.

The military censor's sensitive work remains shrouded in secrecy. A few clues can be garnered from research about perlustration in the early years of Soviet power and the memoirs of a veteran recruited to work for the military censor in Chita in February 1946. V.A. Ivanov, a scholar with access to closed archives by virtue of his position at the St Petersburg Ministry of Internal Affairs University, is perhaps the only historian to have examined the work of the military censor in any depth. ${ }^{54}$ Perlustration in wartime Leningrad was a major undertaking. Between 1941 and 1945 Leningrad’s military censor employed approximately 840 people. Between May 1943 and December 1945 the military censor examined 252 million letters, telegrams and small packages. Over 109,000 items were confiscated and sections excerpted from 2.5 million items. Leningrad's military censor was literally 'drowning' under the weight of correspondence. ${ }^{55}$ Despite Ivanov's research, little is known about the mechanisms by which special communications were compiled, or what the censor was looking for, but several broad points are discernible. The censor aimed to

\footnotetext{
${ }^{54}$ V.S. Izmozik, 'Perluistratsiya v pervye gody sovetskoi vlasti', Voprosy Istorii 8 (1995), 26-35; V.S. Izmozik, Glaza i ushi rezhima gosudarstvennyi politicheski kontrol' za naseleniem Sovetskoi Rossii v 1918-1928 godakh (St Petersburg 1995); Peter Holquist, “"Information is the Alpha and Omega of Our Work”: Bolshevik Surveillance in its Pan-European Context', The Journal of Modern History 69(3) (September 1997), 415-50; Leopol'd Avzereg, 'Ia vskryval vashi pis'ma... Iz vospominanii byvshego tainogo tsenzora MGB', Vremia i my 55 (1980), 224-53, 56 (1980), 254-78; V.A. Ivanov, Missiya ordena: Mekhanizm massovykh repressii v Sovetskoi Rossii v kontse 20-kh - 40-kh gg. (na materialakh Severo-Zapada RSFSR) (St Petersburg 1997); and V.A. Ivanov, 'Voina i tsenzura (fil'tratsiya lozunga "o nerazryvnoi svyazi” leningradskogo fronta i tyla v period velikoi otechestvennoi voiny 1941-1945 gg.', in R. Sh. Ganelii (ed.), Otechestvennaya istoriya i istoricheskaya mysl' v Rossii XIX - XX vekov (St Petersburg 2006), 474-81.

${ }^{55}$ Ivanov, Missiya ordena, op. cit., 283-4.
} 
intercept letters which contained information perceived to damage military or civilian morale, such as references to hunger or destruction and 'harmful' political views. Furthermore, a blacklist of suspect correspondents, whose letters were routinely opened, was maintained. ${ }^{56}$

Intercepted letters confirm that the propaganda claims of widespread care and concern for the glorious defenders of the motherland contrasted with the reality of feeling neglected and unwanted by wider society. One veteran described his disappointment thus:

All my plans for what to do when I was in the army have been broken, and when I was demobilized life progressed by a different path, which I didn’t want it to go (down). ${ }^{57}$

Many veterans clearly did not expect the cold-edged bureaucracy that they encountered. At the beginning of August 1945 another veteran wrote to his family in Tbilisi:

I never expected such a loathsome and outrageous attitude toward the demobilized, but rather the wise and fair requirements of the [demobilization] law. In me boils all of this anger and disgust, and just think how I struggle, shout and inform everybody about these outrages, but all the same it's a 'voice calling in the wilderness' ${ }^{58}$

Another ex-serviceman expressed his anger in a letter to a friend:

I am disappointed with life. War has ruined people, everywhere there are bribes, pull [blat] and lies. I wasn't able to immediately solve one trifling problem how I wanted, without escapades with different bastards. $^{59}$

Veterans hated the endless bureaucracy, lengthy queues and being diverted from one office to another. As one veteran put it:

56 Zubkova, Poslevoennoe sovetskoe obchchestvo, op. cit., 11.

57 TsGA SPb/7384/36/187/168.

58 TsGA SPb/7384/36/149/46.

59 TsGA SPb/7384/36/186/79. Blat was a peculiarly Soviet form of string-pulling. For a more detailed definition of blat and its importance as an informal means of exchange in an economy defined by shortage, see Sheila Fitzpatrick, 'Blat in Stalin's Time', in Stephen Lovell, Alena Ledeneva and Andrei Rogachavskii (eds), Bribery and Blat in Russia: Negotiating Reciprocity from the Middle Ages to the 1990s (London 2000), 166-82. 
You can't find an end anywhere; they only write that there is everything for the demobilized. You go to one institution, and they send you to another and so on. And so you travel from one end of the city to the other without end. ${ }^{60}$

These angry reactions were typical of the new assertive type of citizen forged on the front lines. Many veterans believed that spilt blood and wartime sacrifices entitled them to speak their minds, bang their fists on desks and complain about the treatment they received, even if it had little effect. ${ }^{61}$ Encouraged to think of themselves as victors and believing that military service would be rewarded, many had expected to return as heroes.

Returning soldiers, however, were in a position to anticipate both the difficulties of demobilization and the behaviour of callous and unscrupulous administrators. Despite the best efforts of the military censor, the Red Army was not hermetically sealed from communication with wider society. Sensitive information inevitably escaped the attention of overworked censors. In addition, the censor did not have a monopoly upon the delivery of letters. Soldiers frequently passed letters between themselves, to be delivered by hand by a comrade on leave or recuperating at the rear. Furthermore, the written word was not the only source of information. New recruits or soldiers re-enlisted having recovered from their injuries related valuable information about the home front. Close-knit frontline communities were fertile breeding grounds for rumours about those back home. Rumours, for example, that Jews were sitting out the war in 'cushy jobs' (teplye mestechki) were widespread. ${ }^{62}$ It is hard to believe that soldiers were completely insulated from or ignorant of the difficulties that their families faced. Service families struggling to survive were particularly vulnerable to

\footnotetext{
60 TsGA SPb/7384/36/149/83ob.

61 Weiner, Making Sense, op. cit., 67; and Merridale, Night of Stone, op. cit., 247.

62 G.V. Kostyrchenko, Tainaya Politika Stalina: Vlast' i anti-Semitism (Moscow 2001), 243; Rebecca Manley, “"Where should we resettle the comrades next?" The Adjudication of Housing Claims and the Construction of the Post-War Order', in Juliane Fürst (ed.), Late Stalinist Russia, Society Between Reconstruction and Reinvention (London 2006), 233-44, at 240; Mary M. Leder, ed. Laurie Bernstein, My Life in Stalinist Russia: An American Looks Back (Bloomington and Indianapolis, IN, 2001), 252.
} 
corrupt bureaucrats. The social welfare organizations responsible for assisting service families and the war disabled, for example, were notoriously corrupt and inefficient. Gifts of clothing and footwear delivered from America were frequently 'commandeered’ by administrators, rather than being passed to the needy. ${ }^{63}$ Top secret spetssoobshchenie forwarded to the USSR state prosecutor, based on letters written at the end of 1944 and beginning of 1945, reveal the abuse and beatings soldiers' families suffered at the hands of collective-farm chairmen and village Soviets. ${ }^{64}$ Well before demobilization began, soldiers held a range of preconceived ideas and prejudices toward 'rear-line rats'. However, as exservicemen confronted these 'loathsome’ creatures face to face their responses became more aggressive and resentful.

One of the main sources of tension for returning soldiers was the difficulty of finding employment. Officially unemployment was not a problem for returning veterans. A number of the men I interviewed were steadfast in their support of the official myth that unemployment did not exist in the postwar Soviet Union. Statistics only seem to support this assertion. Between July 1945 and the end of June 1947 a total of 267,253 veterans were demobilized in Leningrad. Of these 258,548 (96.7 per cent) were re-employed. ${ }^{65}$ A further 53,334 disabled veterans were registered with the city's social security administration by the beginning of January 1947, of whom 87.3 per cent were working or in education or training. ${ }^{66}$ However, in the short term many veterans found the mechanisms by which they were reemployed and the jobs they were given frustrating or disappointing. Many blamed the rearline rats for obstructing their reintegration into the workplace. In his memoirs Aleksei Gonchukov was shocked by the reception he received from his pre-war employers, the

${ }^{63}$ TsGAIPD SPb/25/12/66/91-3 and TsGAIPD SPb/25/12/123/26-44ob (I am indebted to Tatiana Voronina for bringing these files to my attention); GARF/A-413/1/1190/23-30; Cynthia Hooper, 'A Darker "Big Deal”: Concealing Party Crimes in the Post-Second World War era', in Juliane Fürst (ed.), Late Stalinist Russia, Society Between Reconstruction and Reinvention (London 2006), 142-63, at 146.

${ }^{64}$ GARF/R-8131/37/2473/58-61, 78-81, 116-119.

65 TsGA SPb/7384/36/226/208.

66 TsGAIPD SPb/24/2v/8230/1. 
gigantic Kirov engineering plant: 'I went back to my factory, and imagine my surprise, when the deputy director for personnel told me with bureaucratic ease that the factory couldn't offer me anything. ${ }^{67}$

Letters intercepted by the military censor reveal that a number of veterans believed employment allocation to be corrupt. In May 1946 E.I. Garison wrote about his experience with the City Office for the Allocation and Distribution of Labour Forces (raspredburo), the administration responsible for assigning work to demobilized soldiers as well as re-evacuees.

Well, there sit such loathsome little people, they do with people what they want and send them where they want, they don't have a single drop of humanity, it's all facts with them \&ndash; this and that piece of paper ... Oh, I'm tired with all this bureaucracy, these formalities and stuffy paperwork ... nearly everybody has lost their conscience.

Unemployed and penniless, he expected better. ${ }^{68}$ Writing in February 1946, G.I. Dorokhin expressed a similar concern that Leningrad had been corrupted;

Leningrad as a city, like all other cities has its bad side, in order to get a job one needs a lot of acquaintances or so-called pull [blat] or a colossal quantity of money . . . If you don’t have money and many acquaintances then they won't send you to work in a profession but to work on seasonal employment. ${ }^{69}$

Seasonal employment was a euphemism for unpopular, low-paid and back-breaking jobs in construction, agriculture and forestry. Former soldiers, especially native Leningraders, were disappointed to find Leningrad, a city with a proud revolutionary heritage, reduced to a place where everything was done 'by blat and for money'. ${ }^{70}$

\footnotetext{
67 TsGAIPD SPb/4000/18/333/159.

68 TsGA SPb/7384/36/186/81.

69 TsGA SPb/7384/36/186/78.

70 TsGA SPb/7384/36/186/83.
} 
The influx of assertive veterans into the city, alongside the waves of returning evacuees, placed bureaucrats under enormous pressure. This was especially the case in the allocation of housing and the administration of housing disputes. A combination of wartime destruction, massive population displacement and mismanagement created a genuine housing crisis in postwar Leningrad, far surpassing difficulties in Moscow. It would take many years to untangle the interlocking web of entitlements and build sufficient housing to make good wartime losses. By 18 February 1947 approximately 59,000 families, including 12,000 veterans’ families and 3000 families of disabled veterans, were on waiting lists to receive housing. ${ }^{71}$ In the course of 1946 a total of 22,967 cases of administrative resettlement, the mechanism by which contested occupancy was resolved, were brought in Leningrad. ${ }^{72}$ Overcrowded, dilapidated and unsanitary housing remained the norm in postwar Leningrad. Yet adequate housing headed veterans' list of expectations. When these expectations were cruelly dashed, corrupt and officious desk-rats were blamed for housing shortages.

M.I. Krylov had lived in Leningrad since 1935, had good references from his employers and had spent two years and eight months in the front line. Five days after his arrival in the city, a letter intercepted by the military censor captured his mood. 'I am in deep despair, defending the motherland I earned the "benefit” of deprivation of our family room.' Faced with the prospect of moving his family into a hostel for single veterans he expressed the burning rage typical of resentful veterans:

all of this [veterans' entitlements and rights] remains empty words, thanks to those who saved their skins deep in the rear camouflaged from the threat of death, who accumulated sizeable capital and now having returned home get the best apartments, we who lived through the horrors of the hardest days of the war once again have to wander around as if we are unworthy of society, for the salvation of which we

\footnotetext{
71 TsGA SPb/7384/25/241/1.

72 TsGA SPb/7384/25/241/7.
} 
spilt our blood and covered the motherland with the everlasting glory of victory and all that to turn up discarded on the edge of life. ${ }^{73}$

It wasn’t just angry young men who had learnt to 'speak veteran'. ${ }^{74}$ An intercepted letter written by a female veteran on 1 August 1945 expressed her equally low regard for bureaucrats. In her mind concern for veterans extended no further than clean floors and a vase of flowers at demobilization points.

When I began to speak to the prosecutor about how my living-space had been demolished and that I had nowhere to live, he tried to change the conversation to any other subject, if only to escape a sore point. I have written a lot, and been around [the relevant offices] a great deal, but I have not received a positive answer from anybody. Mood \&ndash; damnable. It would have been better to have come back earlier, to not return home to see these disgusting bureaucrats, which during the war were able to firmly entrench themselves in the rear, and arrange their own well-being, and now take up prominent positions in order to support their own existence. ${ }^{75}$

Judging by the letters reported in special communications, bureaucracy and corruption in housing allocation were widespread. Writing in June 1946, a veteran was convinced that 'The queue for receiving living space exists as a screen, while space is given out by blat and bribes. It is only possible to get two metres of land on death. ${ }^{76}$ Many veterans were convinced that the system was stacked against them, reporting the endless bribes and bureaucracy they encountered.

Oh, if only you knew what they do with apartments here. If you have ten thousand and you give it to the building administrator, then you will immediately receive a room, but if you like us arrive from the

\footnotetext{
73 TsGA SPb/7384/36/149/47ob.

${ }^{74}$ Here I borrow and deliberately misquote Stephen Kotkin's phrase 'speaking bolshevik'; see Stephen Kotkin, Magnetic Mountain: Stalinism as a Civilization (Berkeley, CA, 1997), 198-237.

75 TsGA SPb/7384/36/149/47.

76 TsGA SPb/7384/36/186/89.
} 
army don't think you will get a room, even if you had a room here before the war. ${ }^{77}$

Estimates of the size of bribes passing hands to obtain accommodation ranged from 3000 to 25,000 roubles, but all of them grumbled about the 'inky pedants' who had tied everything up in red tape. ${ }^{78}$

The strongest expressions of animosity and resentment amongst ex-servicemen were recorded amongst the war disabled, a group who were especially angry about unscrupulous administrators and bureaucrats. Throughout the twentieth century disabled veterans have been pushed to the margins. Seen as a nuisance, embarrassment or burden, their needs have often been ignored or neglected. This was especially true in postwar Leningrad. As a prominent reminder of the horrors of war, disabled ex-servicemen were an unwelcome presence in a city struggling to forget. Intercepted letters written to friends and relatives reveal disabled veterans’ deep disappointment. As Alexandra Ermakova wrote,

It wasn’t worth fighting to become an invalid, in order after the war to obtain this kind of life. When we fought they promised us everything, and how we earned it, but now they give us nothing. If a war happened now I wouldn't fight again, better to shoot me on the spot. ${ }^{79}$

As another war invalid put it, 'We fought and spilt our blood and now our children starve. I don't want to live. ${ }^{, 80}$

During and after the war, government institutions and their staff displayed a particularly callous attitude towards war invalids. Moskvin, a disabled veteran living on the outskirts of Leningrad, summed up the frustrations of many: 'When we were healthy, then they found us, and sent us to the front and crippled us, and now throw us into arbitrary

\footnotetext{
77 TsGA SPb/7384/36/186/74.

78 TsGA SPb/7384/36/186/90 and TsGA SPb/7384/36/149/46ob.

79 TsGA SPb/7384/36/187/55.

80 TsGA SPb/7384/36/187/54.
} 
fates ... while the government does not provide any help. ${ }^{, 81}$ Another veteran, writing in an intercepted letter, questioned the availability of state support, and described propaganda as ‘just blowing smoke in your eyes’ ${ }^{82}$ Disabled veterans, perhaps even more than able-bodied veterans, were acutely aware of the dissonance between propaganda and everyday realities. The process of applying for and claiming disability pensions conflicted with the official pronouncements of state assistance. Applications for social security payments were repeatedly rejected. Hobbling into a district social security office on crutches, one veteran hoped to demonstrate his eligibility for pension. The administrator told him: 'I see that your leg has been amputated, but we won’t pay benefits while you don’t have a certificate., ${ }^{83}$ Given such treatment, it is hardly surprising the disabled veterans reacted with anger, resentment and threats. In January 1945 a police report records war invalid Filippov becoming embroiled in an angry confrontation with the employees of the Os'minskii district social security office. Angered at being sent back to work, he became aggressive, declaring: 'That's it. I've earned the right to work and that's all, you wait, when the frontline soldiers [frontoviki] return home they will show you rear-line spiders [tylovye paukyi] what's what. ${ }^{94}$

Disabled veterans might have expected better treatment from medical or social care administrations. In the summer of 1946 Leningradskaya pravda published a series of articles based on war invalids' letters of complaint about the treatment they received from technicians and doctors responsible for producing and fitting prosthetic limbs. Shipakov, an amputee, wrote

The employees of the factory have forgotten that they are dealing with living people, and are only concerned with somehow knocking together a prosthetic. Whether it is suitable for him, or whether the

\footnotetext{
81 TsGA SPb/7179/53/110/21.

${ }^{82}$ TsGA SPb/7384/36/149/4.

${ }^{83}$ TsGA SPb/7384/36/187/102; Leningrad Oblast State Archive in Vyborg [hereafter 'LOGAV'] R$3824 / 4 / 53 / 4$

${ }^{84}$ TsGA SPb/7179/53/110/21ob.
} 
invalid is able to walk on it, little interests them. The prosthetic [limb] prepared for me was significantly longer than it needed to be. The fitting is [too] wide. But it would have been easy to avoid if while I was being measured the technician and doctor had paid the necessary attention.

Other war invalids were issued with legs that were five centimetres too short, or right arms instead of left. ${ }^{85}$ The uncaring attitude of public officials was particularly apparent in the depressing residential homes created to house disabled veterans without families or alternative means of support. In January 1946 Soboleva, the head of the Leningrad regional social security administration, accused directors of embezzling funds intended to feed disabled veterans. Along with other delegates, she repeatedly reminded directors of their responsibilities toward 'living people' placed in their care. Such neglect only reinforced disabled veterans' feelings of worthlessness. ${ }^{86}$

Leningrad's disabled veterans resented being pushed aside \&ndash; sometimes literally \&ndash; by heartless officials, but also by wider society. Their consciousness of their marginalization in the postwar world, for which they had sacrificed their health, was especially painful. ${ }^{87}$ In a letter to a friend one war invalid explained his frustration at being ignored:

You hear by radio [that everything is] simply splendid, you think that everyone is pleased to see you, but as you begin [to settle in] you aren’t needed by anyone, neither big or small bosses pay you any attention and if you start to argue, you will [be told] that you have one

\footnotetext{
85 'Soveshchanie po voprosu o protezirovanii', Leningradskaya pravda, 18 June 1946, 4; 'Pochemy invalid polychaet polokhoi protez', Leningradskaya pravda, 30 June 1946, 3; 'Spravedlivye trebovaniya (obzor pisem)', Leningradskaya pravda, 18 July 1946, 3.

${ }^{86}$ LOGAV/R-2798/1/65/7ob, 10, 42, 44.

87 Joanna Bourke, Dismembering the Male: Men's Bodies, Britain and the Great War (Chicago, CA, 1996), 5674; Tumarkin, The Living and the Dead, op. cit., 98-9; Merridale, Ivan's War, op. cit., 314; Zubkova, Russia after the War, op. cit., 24; Senyavskaya, Frontovoe pokolenie, op. cit., 32.
} 
leg and survived and [that you should say] thank you that you remained alive. ${ }^{88}$

Despite the state's efforts to reintegrate disabled veterans into the workplace, ordinary Leningraders came, over time, to resent the presence of angry and disaffected war invalids. A secret police report recorded Makeev, a disabled veteran living in the Luzhskii district of the Leningrad region (oblast') complaining that when he returned people looked upon him 'like they would a dog' ${ }^{89}$ The warden of one university dormitory segregated six disabled veterans from other students by placing them in one room. All six were amputees who had lost one or more arms. The desire to avoid the embarrassment, discomfort and reminders of the horrors of war which disfigured and mutilated bodies often provoked frequently overrode disabled veterans' real needs.

Demobilized veterans' complaints about 'rear-line rats' reflected a genuine concern about the difficulties of dealing with the problems created by widespread bureaucracy and corruption. Many sections of the bureaucratic apparatus responsible for transforming exservicemen and ex-servicewomen into ordinary civilians had become increasingly inefficient, bureaucratic and corrupt. ${ }^{90}$ Veterans' accusations of corruption and bureaucratic disdain, contained in opinion reports, are confirmed in other sources. Spetssoobshchenie reflected more than the attitudes of a disaffected minority of veterans, or censors' over-active imaginations. They reflected the reality that many demobilized veterans encountered callous officials and corrupt bureaucrats in the process of adapting to civilian life. In the immediate postwar years the local press frequently contained reports of corruption in institutions with which veterans had active dealings. Several instances of corruption in Offices for the

88 TsGA SPb/7384/36/149/4.

89 TsGA SPb/7179/53/110/20ob.

${ }^{90}$ For a discussion of corruption in the post-war Soviet Union see James Heinzen, 'A “Campaign Spasm”, Graft and the Limits of the "Campaign" against Bribery after the Great Patriotic War', in Juliane Fürst (ed.), Late Stalinist Russia, Society Between Reconstruction and Reinvention (London 2006), 123-4; James Heinzen, 'The Art of the Bribe: Corruption and Everyday Practice and the Late-Stalinist USSR', Slavic Review 66(3) (Fall 2007), 389-412; and Hooper, 'A Darker “Big Deal”', op. cit. 
Allocation and Distribution of Labour Forces (raspredburo), responsible for providing veterans with work assignments, were revealed. ${ }^{91}$ Veterans' complaints about the difficulties of obtaining residence permits (propiska) and finding somewhere to live were supported by procuracy investigations which uncovered cases of housing officials issuing documents or allocating vacant housing in exchange for bribes. ${ }^{92}$ Although the military censor attempted to intercept private correspondence which attacked 'rear-line rats', bureaucracy and corruption remained public knowledge. According to White, the city Soviet was waging a public war with its housing departments in the pages of Leningradskaya pravda and Vechernyi Leningrad, with accusations of bureaucracy, corruption and rudeness appearing in almost every issue. ${ }^{93}$ The letters pages of newspapers regularly reported the protracted bureaucratic battles waged by veterans to reclaim or obtain housing. ${ }^{94}$ Compared with the disaffected and disenchanted vilification of intercepted letters, letters of complaint published in the press were a mild form of Bolshevik self-criticism. Veterans deeply resented the fact that queues, delays and red tape could be avoided with the correct connections and the necessary sums in cash.

The experience of demobilization, for the majority of veterans returning to Leningrad and the surrounding region, was far from smooth. Demobilization, of course, created both winners and losers. A lucky few were able to return to their families, homes and workplaces and resume their lives with a minimum of disruption. An even smaller number of veterans were promoted to managerial positions and benefited from increased social mobility and enhanced social status. But most veterans found the process of resuming normal lives extremely difficult. Although former soldiers were theoretically guaranteed a wide range of

\footnotetext{
91 Leningradskaya pravda, 16 March 1945, 4. See also White, ‘After the War was Over’, op. cit., 1153; 'Sud zhuliki', Vechernyi Leningrad, 18 July 1946, 4.

92 TsGA SPb/7384/36/227/44-5.

93 White, After the War was Over', op. cit., 1155.

94 'Zatyanuvsheesya delo', Smena, 25 October 1945, 3; 'Tri mesyatsa volokity’, Leningradskaya pravda, 15 August 1946, 3.
} 
privileges, in practice they were rarely protected from the harsh realities of everyday life in postwar Leningrad. Demobilized Leningraders complained that privilege existed on paper well before the majority of entitlements and privileges were cancelled in September and December $1946 .{ }^{95}$ Worse still, Leningrad's veterans, like their counterparts across the Soviet Union, or for that matter Europe, resented men who had escaped uniformed service. Grumbling about shirkers was just as much part of the culture of the Red Army and its veterans as any other modern mass conscript army. When homecoming failed to live up to expectations, 'rear-line rats' became the scapegoats for disenchanted veterans. Public attacks and denunciations of bureaucrats carried in local and regional newspapers further encouraged veterans to vent their spleens at minor state functionaries, rather than the party leaders of the Soviet political system. Contrary to what one reads in the postwar press or what the few surviving veterans might tell you today, returning veterans, regardless of age, gender or disability, were disoriented and disenchanted by the welcome they received in postwar Leningrad.

The postwar history of Leningrad and its former soldiers is shrouded in myth. Rather than bringing people together, the war's legacy continued to damage social cohesion and create deeply rooted tensions. The animosity directed at 'rear-line rats' was just one example of the wartime divisions that simmered under the surface of late Stalinist society. Although the story of the durability of ordinary Leningraders in the face of mass death and starvation remains humbling and the narrative of postwar reconstruction continues to impress, the city and its people were deeply shaken by the experience of war. The cost of the war could not simply be measured on a balance sheet of lives lost, money spent and infrastructure destroyed. Yet the social costs of war have largely been obscured by the heroic postwar myths. The official image of veterans as exemplary citizens has proved remarkably durable.

95 Edele, 'Soviet Veterans as an Entitlement Group’, op. cit., 125-6. 
The images of bunting, bouquets and cheering crowds and the myth of a 'Hero City' unbroken by war were much more palatable than the reality of widespread anger and resentment amongst veterans. With the passing of time the frustrations and disappointments of demobilization gradually subsided. By the time that former soldiers finally received the recognition that they had expected on their return they were already entering old age. The developing cult of war, steadily improving welfare payments and improving social welfare, secured veterans' support for the official version of demobilization. Mythology helped many veterans make sense of the horrors of war and of their lives. For the ever-dwindling number of Great Patriotic War veterans the battle lines had been redrawn. Patriotic myths no longer provoked angry reactions but offered renewed comfort and pride.

\section{Robert Dale}

is a PhD student at Queen Mary, University of London. He is working on a thesis exploring the postwar adaptation of Red Army veterans in Leningrad between 1944 and 1950. He currently holds a Dissertation Fellowship from the Harry Frank Guggenheim Foundation. 